\title{
Pendapat Imam Syafi'i tentang Hak Ijbar Wali: Suatu Kajian Berperspektif Gender
}

\author{
Ayi Ishak Sholih Muchtar \\ Institut Agama Islam Darussalam (IAID) Ciamis, Jawa Barat \\ Email: ayi.ishaksm@gmail.com \\ Rd. Zihad \\ Institut Agama Islam Darussalam (IAID) Ciamis, Jawa Barat \\ Ita Puspitasari \\ Institut Agama Islam Darussalam (IAID) Ciamis, Jawa Barat
}

\begin{abstract}
ABSTRAK
Salah satu akibat dari masih sempitnya pemahaman masyarakat dalam memahami hak ijbar wali adalah masih mengakar kuatnya budaya kawin paksa. Hak ijbar yang seharusnya dimaknai sebagai bentuk perlindungan atau tanggung jawab seorang ayah terhadap anaknya. Karena keadaan anaknya yang dianggap belum atau tidak memiliki kemampuan untuk bertindak sendiri dalam pernikahan, malah dipahami sebagai alat untuk melegitimasi tindakan orang tua untuk memaksa anaknya kawin atau menikahkan anaknya dengan pilihannya, bukan pilihan anaknya. Hal ini dikarenakan adanya Perbedaan para Ulama serta hak ijbar juga menjadi perdebatan apalagi jika dihadapkan dengan isu-isu kontemporer seperti gender.
\end{abstract}

\begin{abstract}
One result of the still limited understanding of the community in understanding the rights of ijbar wali is that the culture of forced marriage is still rooted. Ijbar rights that should be interpreted as a form of protection or responsibility of a father towards his child. Because the condition of the child who is considered not yet or does not have the ability to act alone in marriage, it is even understood as a tool to legitimize the actions of parents to force their children to marry or marry their children with their choice, not their children's choice. This is because there are differences in Ulama and Ijbar rights which are also debated especially when faced with contemporary issues such as gender.
\end{abstract}

Keywords: Ijbar rights, Imam Shafi'i, gender perspective 


\section{PENDAHULUAN}

Pada hakikatnya laki-laki dan perempuan diciptakan Allah SWT guna menjadikan keduanya pasangan yang lengkap dan agar saling mengenal. Atas dasar itu, prinsip al-Quran terhadap hak laki-laki dan perempuan adalah sama, hak isteri diakui secara adil dengan hak suami. Keduanya memiliki hak dan kewajiban masing-masing. Oleh sebab itu, perkawinan tidak saja dipandang sebagai media mereleasasikan syari'at Allah agar memperoleh kebaikan di dunia dan di akhirat, tetapi juga merupakan sebuah kontrak perdata yang akan menimbulkan hak dan kewajiban antar keduanya (Sahrani, 2009: 153).

Sebagaimana firman Allah SWT dalam surat an-Nisâ (4): 1:

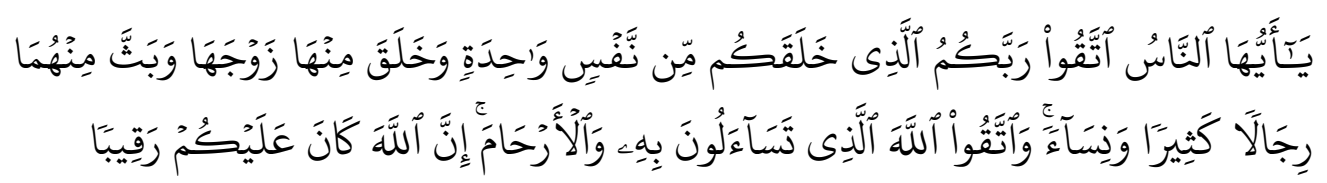

Hai sekalian manusia, bertakwalah kepada Tuhan-mu yang telah menciptakan kamu dari seorang diri, dan dari padanya Allah menciptakan isterinya; dan dari pada keduanya Allah memperkembang biakkan laki-laki dan perempuan yang banyak. dan bertakwalah kepada Allah yang dengan (mempergunakan) nama-Nya kamu saling meminta satu sama lain, dan (peliharalah) hubungan silaturrahim. Sesungguhnya Allah selalu menjaga dan mengawasi kamu. (Q.S An-Nisâ, 4: 1)

Tujuan perkawinan adalah untuk membina keluarga yang bahagia, diliputi rasa cinta dan kasih sayang dan diridhai Allah SWT. Tujuan ini akan tercapai apabila calon-calon mempelai telah saling suka menyukai untuk mengadakan ikatan perkawinan. Saling suka menyukai ini dalam bentuk yang lahir berupa izin dan persetujuan pihak-pihak yang akan melakukan perkawinan itu sendiri. Karena pihak wanita tidak secara langsung melaksanakan ijab, maka agama mengisyaratkan adanya izin dan persetujuan dari seorang wanita sebelum dilaksanakan perkawinannya (Muchtar, 1993: 97).

Kenyatannya seringkali masih kita jumpai sebagian masyarakat yang memahami ajaran Islam dari arah figh secara sempit. Salah satu akibat sempitnya dalam memahami ajaran figh ini adalah masih mengakar kuatnya budaya kawin paksa. Hal ini terjadi karena dalam tradisi masyarakat Indonesia masih terdapat anggapan yang sangat kuat bahwa jodoh bagi anak laki-laki adalah urusan Tuhan, tetapi bagi anak perempuan adalah urusan orang tua yang dalam hal ini adalah bapaknya. Pandangan ini kemudian melahirkan pemahaman yang keliru terhadap apa yang dikenal dengan hak ijbar.

Hak ijbar yang dimiliki oleh wali mujbir seharusnya dimaknai sebagai hak yang dimiliki orang tua untuk menikahkan anak perempuannya atas 
dasar tanggung jawab. Namun praktik pelaksanaan hak ijbar ini mengalami penyimpangan. Hal ni karena adanya pergeseran makna terhadap pemahaman ijbar yang lalu menimbulkan asumsi bahwa Islam membenarkan adanya kawin paksa. Kawin paksa sendiri merupakan salah satu istilah yang memiliki konotasi ikrah. Menurut Muhammad (2002: 106), yang merupakan aktifis pembela hak-hak perempuan mengatakan, bahwa ikrah merupakan suatu bentuk paksaan terhadap seseorang untuk melakukan satu pekerjaan disertai dengan suatu ancaman yang mengancam jiwa dan tubuhnya, tanpa dia sendiri mempu melawannya. Sementara bagi orang yang dipaksa, perbuatan tersebut bertentangan dengan kehendak hati nurani dan pikirannya.

Hadits Nabi Muhammad SAW:

$$
\begin{aligned}
& \text { أخبرنا محمد بم عبد الاعلى قال حد ثنا خالد وهو بن الحرث قال حدثنا هشام عن ييى بن ابي كثير قال }
\end{aligned}
$$

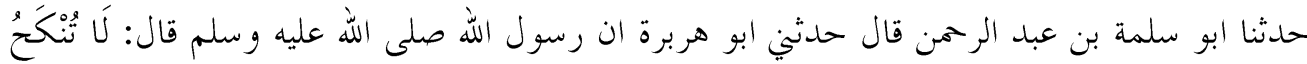

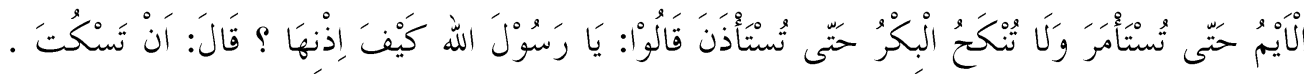

$$
\begin{aligned}
& \text { (رواه النساءي) }
\end{aligned}
$$

“Berkata kepadaku Abu Hurairah bahwasanya Rasulullah SAW berkata: Tidak boleh dinikahkan parajanda sehingga ia diajak musyawarah dan tidak boleh dinikahkan seorang gadis sehingga dimintai izinnya, mereka bertanya: Ya Rasulullah, bagaimana izinnya? Rasulullah SAW. menjawab: diamnya" (An-Nasa'i juz VI, tt: 86).

Imam Syafi'i dan Ulama yang lain menetapkan hak ijbar bagi seorang wali atas dasar kasih sayangnya yang mendalam terhadap putrinya itu. Seorang ayah adalah sosok yang begitu peduli pada kebahagiaan anak gadisnya. Sebab sang gadis belum berpengalaman hidup berumah tangga, disamping biasanya ia pun malu untuk mencari pasangan sendiri, sehingga para Ulama mencoba memberikan saran bagi ayah untuk membantu buah hatinya itu. Karenanya, Syafi'i hanya memberikan hak ijbar kepada ayah semata. Walaupun dalam perkembangan selanjutnya Ashab (sahabatsahabat) Syafi'i memodifikasi konsep itu dengan memberikan hak ijbar juga pada kakek (Sopariyanti, 2008: 15).

Dalam konteks masa kini, hak ijbar juga menjadi perdebatan apalagi jika dihadapkan dengan isu-isu kontemporer seperti gender. Konsep ijbar ini dianggap bertentangan dengan kesetaraan dan keadilan gender. Dengan kata lain dianggap merenggut hak perempuan apalagi dalam hak ijbar, wali mujbir berhak menikahkan anak perempuannya walaupun tanpa persetujuan yang bersangkutan serta ada anggapan bahwa seorang perempuan lemah dalam bertindak dan tidak mampu membuat keputusan sendiri (Dewi, 2017: 3). 


\section{LANDASAN TEORI}

Konsep Wali Nikah

Menurut Summa (2004: 134), wali juga berarti kekuasaan/otoritas (assulthah walqudrah), seperti dalam ungkapan al-wali, yakni orang yang mempunyai kekuasaan. Hakikat dari al-walayah (al-wilayah) adalah tawally alamr (mengurus/ menguasai sesuatu). Sedangkan dalam Kamus Besar Bahasa Indonesia, wali diartikan sebagai pengasuh pengantin perempuan ketika nikah, yaitu orang uang melakukan janji nikah dengan laki-laki (KBBI, 1989: 1007).

Sedangkan menurut istilah Figh, perwalian ialah penguasaan penuh yang diberikan oleh agama kepada seseorang untuk melakukan, menguasai dan melindungi orang atau barang. Penguasaan dan perlindungan itu disebabkan oleh:

1) Pemilikan orang atas orang atau barang, seperti perwalian atau budak yang dimiliki atau barang-barang yang dimiliki.

2) Hubungan kerabat atau keturunan, seperti perwalian seseorang atas salah seorang kerabtnya atau anak-anaknya.

3) Karena memerdekakan budak, seperti perwalian seseorang atas budak yang dimerdekakannya.

4) Karena pengangkatan, seperti perwalian seseorang kepala negara atas rakyatnya atau perwalian seseorang pemimpin atas orang yang dipimpinnya (Muchtar, 1993: 93).

Secara bahasa perwalian dalam Syari'at Islam berarti pertolongan atau bantuan atau orang yang mempunyai tanggung jawab untuk melaksanakan urusan orang lain dan menguasai serta mengurusi perkara orang lain tersebut. Sedangkan perwalian menurut istilah adalah suatu hak untuk mengucapkan suatu ucapan (akad) atas orang lain baik ia menghendakinya atau tidak, dikarenakan kelemahan yang dimiliki oleh orang lain tersebut dan minimnya keahlian untuk melaksanakan transaksi atas dirinya sendiri (Effendi, 1991: 234).

Secara hukum, kedudukan wali diatur antara lain dalam firman Allah dalam surat an-Nur ayat 32:

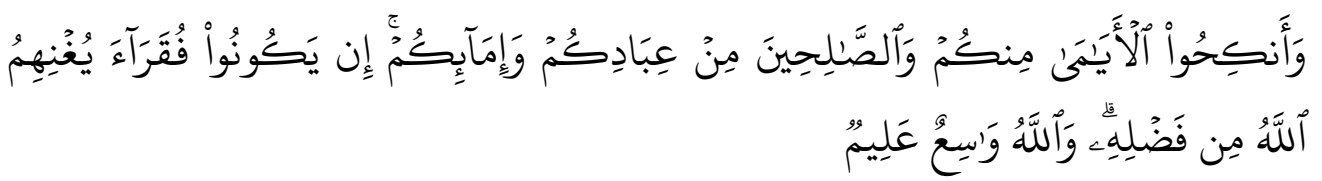

"Dan kawinkanlah orang-orang yang sedirian diantara kamu, dan orang-orang yang layak (berkawin) dari hamba-hamba sahayamu yang lelaki dan hamba-hamba sahayamu yang perempuan. jika mereka miskin 
Allah akan memampukan mereka dengan kurnia-Nya. dan Allah Maha Luas (pemberian-Nya) lagi Maha mengetahui". (Q.S an-Nuur, 24: 32).

1) Hadits Nabi Muhammad SAW dari Abu Musa R.A yang menegaskan pentingnya wali dalam pernikahan:

$$
\text { عن أبي موسى قال: قال رسول الله صلى الله عليه وسلم لا نكاح الا بولي. }
$$

"Dari Abi Musa berkata: berkata Rasulullah SAW: Tidak ada nikah kecuali dengan adanya wali". (Musnad Abu Dawud kitab an-Nikah bab fi al-wali hadits no. 1785)

Syarat-Syarat Menjadi Wali

1) Telah dewasa dan berakal sehat dalam artian anak kecil atau orang gila tidak berhak menjadi wali.

2) Laki-laki. Tidak boleh perempuan menjadi wali. Dalilnya adalah hadits Nabi Muhammad SAW dari Abu Hurairah yang telah dikutip di atas. Ulama Hanafiyah dan Ulama Syiah Imamiyah mempunyai pendapat yang berbeda dalam persyaratan ini. Menurut mereka perempuan yang telah dewasa dan berakal sehat dapat menjadi wali untuk dirinya sendiri dan dapat menjadi wali untuk perempuan lain yang mengharuskan adanya wali. Sebagaimana dijelaskan di atas.(Syarifuddin, 2006: 73)

3) Muslim, tidak sah orang yang tidak beragama Islam menjadi wali untuk orang muslim. Hal ini berdalil dari firman Allah SWT dalam surat Ali Imran ayat 28

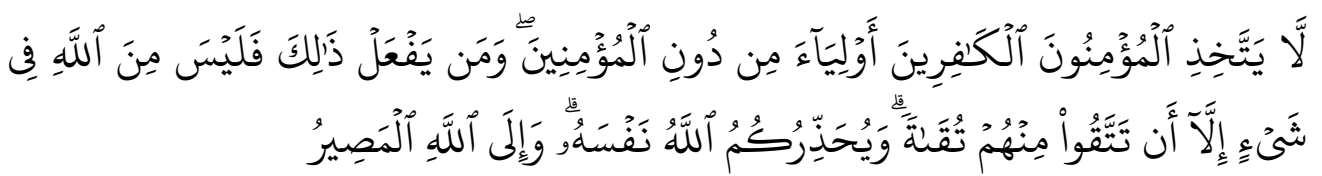

Janganlah orang-orang mukmin mengambil orang-orang kafir menjadi wali dengan meninggalkan orang-orang mukmin. barang siapa berbuat demikian, niscaya lepaslah ia dari pertolongan Allah, kecuali karena (siasat) memelihara diri dari sesuatu yang ditakuti dari mereka. dan Allah memperingatkan kamu terhadap diri (siksa)-Nya. dan hanya kepada Allah kembali (mu). (Q.S Ali Imran, 3: 28)

4) Orang merdeka.

5) Berpikiran baik, orang yang terganggu pikirannya karena ketuaannya tidak boleh menjadi wali, karena dikhawatirkan tidak akan mendatangkan mashlahat dalam perkawinan tersebut (Syarifuddin, 2006: 78). 
6) Adil, dalam artian tidak pernah terlibat dalam dosa besar dan sering terlibat dalam dosa kecil serta tetap memelihara sopan santun.

7) Tidak sedang melakukan ihram untuk haji atau umrah. Dalam hal persyaratan ini Ulama Hanafiyyah mengemukakan pendapat yang berbeda. Menurut mereka wali yang melakukan ihram dapat menikahkan pasangan yang sedang ihram (Syarifuddin, 2006:82).

Macam-macam Wali

1) Wali Nasab

Wali nasab artinya anggota keluarga laki-laki dari calon mempelai perempuan yang mempunyai hubungan darah patrilineal dengan calon mempelai perempuan. Wali nasab mempunyai kedudukan sebagai orang yang bisa menikahkan calon mempelai perempuan. Wali nasab terbagi menjadi dua:

\section{2) Wali Mujbir}

Wali Mujbir adalah wali nasab yang berhak memaksakan kehendaknya untuk menikahkan calon mempelai perempuan tanpa meminta izin kepada wanita yang bersangkutan. Hak yang dimiliki wali mujbir disebut dengan hak ijbar. Dalam hal ini Syafi'iyyah membatasi hak ijbar hanya dimiliki ayah dan kakek. Ualam Hanafiyah menempatkan seluruh kerabat nasab, baik sebagai asabah dalam kewarisan atau tidak. Sebagai wali nasab termasuk dzawil arham (Syarifuddin, 2006: 78).

\section{3) Wali Nasab Biasa}

Wali nasab biasa adalah wali nasab yang tidak mempunyai kewenangan untuk memaksa menikahkan tanpa izin atau persetujuan dari wanita yang bersangkutan dengan kata lain wali nasab biasa tidak memiliki kewenangan untuk menggunakan hak ijbar (Hernawati dan Mukhlisin, 2008: 35).

Jumhur Ulama yang terdiri dari Syafi'iyah, Hanabilah, Zhahiriyah dan Syiah Imamiyah membagi wali kedalam dua kelompok: Pertama, wali dekat atau wali qarib yaitu ayah, kalau tidak ayah pindah ke kakek. Keduanya mempunyai kekuasaan yang mutlak terhadap anak perempuan yang akan dikawinkannya. Ia dapat mengawinkan anaknya yang masih berada dalam usia muda tanpa meminta persetujuan dari anaknya tersebut. Ketidakharusan meminta pendapat dari anak yang masih muda itu karena tidak mempunyai kecakapan untuk memberi persetujuan. Ulama Hanabilah menempatkan orang yang diberi wasiat oleh ayah untuk mengawinkan anaknya berkedudukan sebagai ayah.

Kedua, wali jauh atau wali $a b^{\prime} a d$, yaitu wali dalam garis kerabat selain ayah dan kakek, juga selain anak dan cucu, karena anak menurut Ulama jumhur tidak boleh menjadi wali terhadap ibunya dari segi dia adalah anak. 
Bila anak berkedudukan seagai wali hakim boleh dia mengawinkan ibunya sebagai wali hakim. adapun wali $a b^{\prime} a d$ adalah sebagai berikkut: a) Saudara laki-laki kandung; b) Saudara laki-laki seayah; c) Anak saudara laki-laki kandung; d) Anak saudara laki-laki seayah; e) Paman kandung; f) Paman seayah; g) Anak laki-laki paman kandung; g) Anak laki-laki paman seayah; h) Saudara laki-laki kakek sekandung; i) Saudara laki-laki kakek seayah; j) Anak laki-laki saudara laki-laki kakek sekandung; k) Anak laki-laki saudara laki-laki kakek seayah; l) Saudara buyut sekandung; m) Sadara buyut seayah; n) Anak laki-laki buyut sekandung; o) Anak laki-laki buyut seayah; p) Ahli waris kerabat lainnya kalau ada (Hernawati dan Mukhlisin, 2008: 35).

\section{4) Wali Hakim}

Wali hakim adalah wali nikah yang ditunjuk oleh pemerintah. Di Indonesia wali hakim adalah wali yang ditunjuk oleh Menteri Agama atau pejabat yang ditunjuk olehnya, yang diberikan hak dan kewenangan untuk bertindak sebagai wali nikah. Wali hakim diatur dalam peraturan Menteri Agama No 2 tahun 1987 tentang wali hakim. Wali hakim dapat bertindak sebagai wali nikah apabila:

a) Wali nasab tidak ada: memang tidak ada (kemungkinan calon mempelai sudah tidak mempunyai lagi wali untuk menikahkannya, dalam artian semua wali nasab yang memnuhi syarat sebagai wali telah meninggal dunia atau calon mempelai wanita tidak mempunyai wali karena wali berlainan agama atau calon mempelai perempuan merupakan anak yang dilahirkan di luar pernikahan).

b) Wali nasab tidak mungkin hadir: karena berpergian sejauh masafakul qasri $(92,5 \mathrm{~km})$ dan sulit dihubungi, berhaji atau melaksanakan umrah.

c) Wali nasab tidak diketahui tempat tinggalnya.

d) Wali nasab ghaib (mafqud): diperkirakan masih hidup tapi tidak diketahui rimbanya.

e) Wali nasab adhal atau enggan menikahkan (setelah ada putusan Pengadilan Agama tentang wali tersebut). Wali adhal adalah wali yang enggan menikahkan wanita yang telah baligh dan berakal dengan seorang laki-laki pilihannya (Hernawati dan Mukhlisin, 2008: 36).

f) Wali Muhakkam

Kalau tidak ada semua wali yang tersebut dan tidak ada hakim agama atau kepala urusan agama Islam pada suatu tempat maka calon mempelai wanita dan pria boleh mengangkat atau mengakui seorang laki-Iaki muslim sebagai wali unluk mengawinkannya. Tetapi laki-Iaki itu hendaklah seorang mujtahid, paling tida kseorang yang bersifat adil dan berakal sehat (Daly,1998. 138). 
Kedudukan wali dalam pernikahan diatur di dalam Surat alBaqarah,2: 232

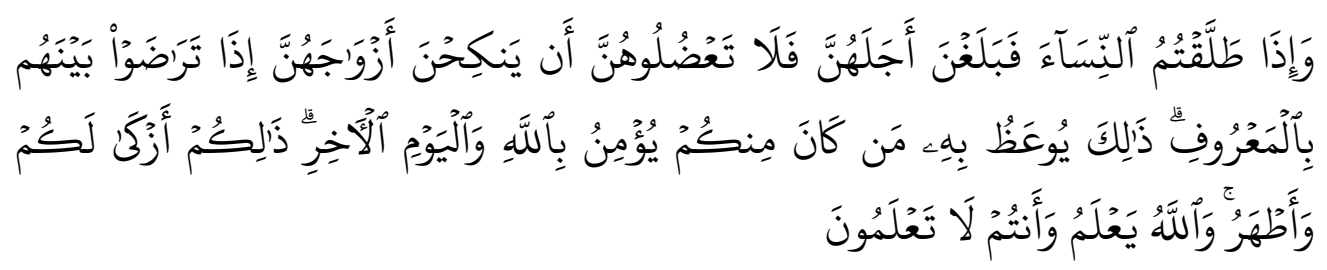

Kemudian Surat al-Baqarah,2: 221

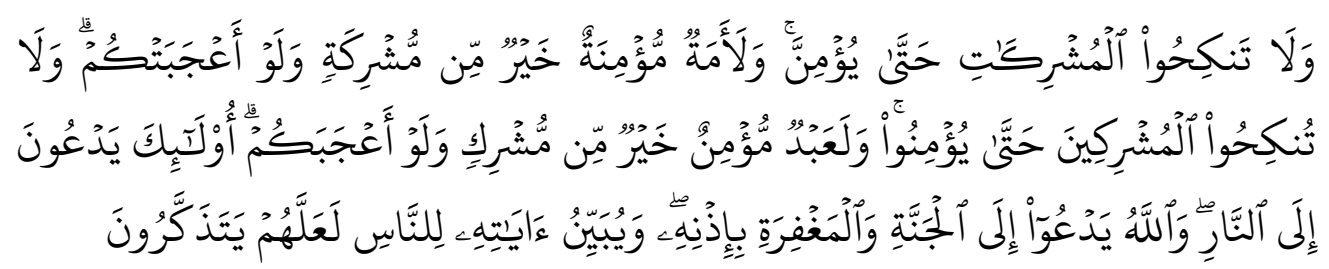

Dan janganlah kamu menikahi wanita-wanita musyrik, sebelum mereka beriman. Sesungguhnya wanita budak yang mukmin lebih baik dari wanita musyrik, walaupun Dia menarik hatimu. dan janganlah kamu menikahkan orang-orang musyrik (dengan wanita-wanita mukmin) sebelum mereka beriman. Sesungguhnya budak yang mukmin lebih baik dari orang musyrik, walaupun Dia menarik hatimu. mereka mengajak ke neraka, sedang Allah mengajak ke surga dan ampunan dengan izin-Nya. dan Allah menerangkan ayat-ayat-Nya (perintah-perintah-Nya) kepada manusia supaya mereka mengambil pelajaran. (Q.S al-Baqarah,2: 221)

Lalu, Surat an-Nur, 24: 32

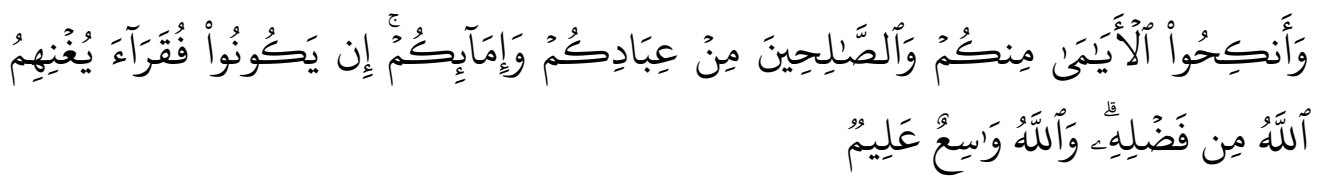

"Dan kawinkanlah orang-orang yang sedirian diantara kamu, dan orang-orang yang layak (berkawin) dari hamba-hamba sahayamu yang lelaki dan hamba-hamba sahayamu yang perempuan. jika mereka miskin Allah akan memampukan mereka dengan kurnia-Nya. dan Allah Maha Luas (pemberian-Nya) lagi Maha mengetahui". (Q.S an-Nur, 24: 32)

Ibarat nash ketiga ayat diatas tidak menunjukkan keharusan adanya wali, karena yang pertama larangan menghalangi perempuan yang habis masa iddahnya untuk kawin, ayat kedua larangan perkawinan perempuan muslimah dengan laki-laki musyrik, sedangkan ayat ketiga suruhan untuk mengawinkan orang-orang yang masih bujang. Namun dalam ketiga ayat itu khitab Allah SWT berkenaan dengan perkawinan dialamatkan kepada wali, dapat pula dipahami daripada keharusan adanya wali dalam perkawinan. Dari pemahaman ketiga ayat tersebut Jumhur Ulama 
menetapkan keharusan adanya wali dalam perkawinan (Syarifuddin, 2006: 86).

\section{Urutan Hak Kewalian}

Pada dasarnya yang menjadi wali itu adalah wali nasab yang qarib. Bila wali qarib tersebut tidak memenuhi syarat baligh, berakal, Islam, merdeka, berpikiran baik dan adil, maka perwalian bukan berpindah kepada wali $a b^{\prime} a d$, tetapi pindah kepada wali hakim secara kewalian umum. Demikian pula wali hakim menjadi wali nikah bila keseluruhan wali nasab sudah tidak ada, atau wali qarib dalam keadaan adhal atau enggan menikahkan tanpa alasan yang dapat dibenarkan. Begitu pula akad perkawinan dilakukan oleh wali hakim bila wali qarib sedang berada di tempat lain yang jaraknya mencapai dua marhalah (sekitar $60 \mathrm{~km}$ ) demikian adalah menurut jumhur Ulama (Syarifuddin, 2006: 98).

Hak Ijbar Wali

Secara etimologi kata ijbar berasal dari kata dasar اكرهل, والزمه, امر yang berarti memaksakan dan mewajibkan untuk melakukan sesuatu. Pengertian ijbar berdasarkan kata dasarnya juga berarti قهر (memaksa) dan الالزم (pemaksaan) (Munawir, 1997: 164-165).

Secara terminologis kata ijbar adalah kebolehan bagi ayah atau kakek untuk menikahkan anak perempuan yang masih gadis tanpa seizinnya. Dengan demikian ayah lebih berhak terhadap anaknya yang masih gadis dari pada anak itu sendiri. Dalam pengertian figh, ayah atau kakek dapat menikahkan anak perempuannya tanpa dibutuhkan persetujuan dari yang bersangkutan, yaitu perempuan yang masih gadis atau yang keperawanannya hilang bukan akibat hubungan seksual misalnya terjatuh, kemasukan jari atau semacamnya (Hidayat, 2009: 12).

Ijbar juga perlu dibedakan dengan ikrah. Ikrah adalah tindakan yang tidak bertanggung kawab, melanggar HAM, dan terkadang disertai dengan ancaman. Pemaksaan ini dilakukan oleh orang-orang yang kurang bertanggung jawab terhadap si gadis. Sedangkan ijbar adalah tindakan untuk melakukan perkawinan bagi anak gadisnya atas dasar tanggung jawab yang hanya bsia dilakukan oleh ayah dan kakek. Ijbar dimaksudkan sebagai bentuk perlindungan atau tanggung jawab seorang ayah terhadap anaknya. Karena keadaan ankanya yang dianggap belum atau tidak memiliki kemampuan untuk bertindak (Muhammad, 2002: 80).

Dengan memahami makna ijbar, kekuasaan ayah untuk menikahkan anak perempuannya hanyalah hak mengawinkan saja, bukan tindakan memaksakan kehendaknya sendiri tanpa memperhatikan kerelaan sang 
anak. Dengan demikian hak ijbar seorang ayah lebih menekankan aspek tanggung jawab, dengan asumsi dasar bahwa anak perempuannya belum atau tidak memiliki kemampuan untuk bertindak sendiri (Hidayat, 2009: 13).

\section{Konsep Gender dalam Islam}

Istilah gender pertama kali diperkenalkan oleh Robert Stoller (1968) untuk memisahkan pencirian manusia yang didasarkan pada pendefinisian yang bersifat sosial budaya dengan pendefinisian yang berasal dari ciri-ciri fisik biologis. Dalam ilmu sosial orang yang juga berjasa dalam mengembangkan istilah dan pengertian gender ini adalah Ann Oakley (1972). Sebagaimana Stoller, Oakley mengartikan gender sebagai kontruksi sosial atau atribut yang dikenakan pada manusia yang dibangun oleh kebudayaan manusia (Nugroho, 2008: 3). Gender menurut Kate Millet adalah istilah yang mempunyai konotasi psikologis dan kultural, bukan berkonotasi biologis. Laki-laki (male) dan perempuan (female) adalah istilah untuk sex (jenis kelamin), sedangkan maskulin dan feminim adalah istilah gender (Millet, 2009: 67).

Gender adalah peran-peran sosial yang dikonstruksikan oleh masyarakat. Peran-peran tersebut berkaitan dengan tugas, sifat, fungsi, hak dan kewajiban serta kesempatan antara laki-laki dan perempuan yang dibentuk oleh ketentuan sosial, nilai-nilai yang berlaku dan budaya lokal. Artinya, laki-laki dan perempuan memiliki ketentuan bersikap dan berperan sesuai dengan harapan masyarakatnya. Masyarakat yang memiliki pandangan bahwa laki-laki adalah mahluk perkasa dan perempuan adalah lemah lembut, maka itulah perspektif gender masyarakat setempat. Demikian halnya dengan konstruksi masyarakat tentang laki-laki itu pemberani, perempuan itu penakut, laki-laki itu rasional, perempuan itu emosional, Laki-laki itu aktif dan perempuan pasif dan seterusnya. Masingmasing ras, suku dan bangsa mempunyai aturan, norma dan budaya gender yang khas, berbeda antara satu etnis dengan etnis lainnya. (Aziz, 2015: 11).

Menurut Zaprulkhan (2015: 113), perbedaan yang jelas antara gender dan sex adalah jika gender secara umum digunakan untuk mengidentifikasi perbedaan laki-laki dan perempuan dari aspek sosial budaya, maka istilah sex secara umum dipakai untuk mengidentifikasi perbedaan laki-laki dan perempuan dari segi anatomi biologi. Istilah sex lebih banyak berkonsentrasi pada aspek biologi seseorang, meliputi perbedaan komposisi kimia dan hormon dalam tubuh, anatomi fisik, reproduksi dan karakteristik biologis lainnya. Sedangkan gender lebih banyak berkonsentrasi pada aspek sosial, budaya, psikologis dan aspek-aspek non biologis lainnya.

Gender dalam Hukum Islam

Secara historis telah terjadi dominasi dalam semua masyarakat sepanjang zaman. Kecuali dalam masyarakat matriarkal, yang jumlahnya 
tidak seberapa. Perempuan dianggap lebih rendah daripada laki-laki. Dari sinilah muncul doktrin ketidaksetaraan antara laki-laki dan perempuan. Perempuan tidak cocok memegang kekuasaan ataupun memiliki kemampuan yang dimiliki oleh laki-laki dan karena itu, dianggap tidak setara dengan laki-laki. Laki-laki harus memiliki dan mendominasi perempuan, menjadi pemimpinnya dan menentukan masa depannya, dengan bertindak baik sebagai ayah, saudara laki-laki ataupun suami. Alasannya, untuk kepentingannyalah dia harus tunduk kepada jenis kelamin yang unggul. Dengan dibatasi di rumah dan dibatasi di dapur, dia dianggap tidak mampu mengambil keputusan diluar wilayah. Akan ada malapetaka yang sangat besar dengan dikatakan apabila perempuan menjadi penguasa sebuah negeri (Engineer, 1994: 55).

Meskipun begitu, semua ketidaksesuaian terhadap perempuan ini hendaknya tidak menjadikan agama sebagai penyebab utama. Orang juga harus melihat agama dalam konteks sosiologis atau sosio-historis tertentu yang kongkret. Akan lebih benar untuk mengatakan bahwa masyarakat patriarkislah yang bertanggung jawab terhadap status inferior perempuan seperti itu. Teks-teks skriptualis tanpa kecuali telah ditafsirkan oleh lakilaki. Bahkan mereka mengembangkan lebih jauh untuk menemukan apa yang tidak ada dalam kitab suci (Engineer, 2003: 66).

\section{Kesetaraan dan Keadilan antara Laki-laki dan Perempuan dalam Kepemimpinan}

Kepemimpinan laki-laki terhadap perempuan adalah bentuk kepemimpinan yang bersifat demokratis, kepemimpinan yang memberikan kebebasan bagi yang dipimpin untuk bertindak menurut aspirasi dan kehendaknya sendiri, baik dalam hal memilih pekerjaan dan pendidikannya. Bukan kepemimpinan yang sifatnya paksaan, yaitu orang yang dipimpin dipaksa mengikuti kehendak yang telah digariskan oleh yang memimpin. Oleh karena itu, posisi menempatkan laki-laki sebagai pemimpin terhadap perempuan bukan berarti menunjukkan bahwa derajat perempuan berada di bawah laki-laki. Akan tetapi hal itu menunjukkan suatu bentuk kerja sama yang baik (Ismail, 2003: 183-184).

Dalam surat an-Nisâ ayat 34 dijelaskan bahwa:

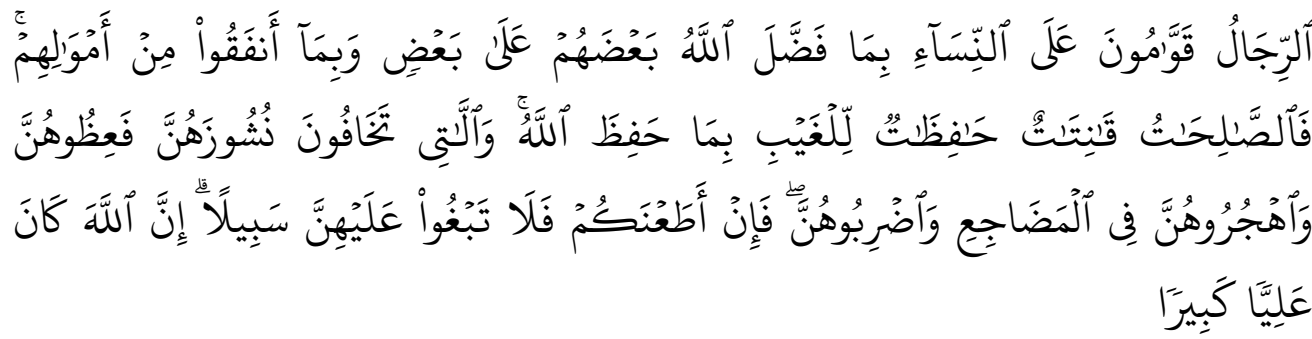

Kaum laki-laki itu adalah pemimpin bagi kaum wanita, oleh karena Allah telah melebihkan sebahagian mereka (laki-laki) atas sebahagian yang lain 
(wanita), dan karena mereka (laki-laki) telah menafkahkan sebagian dari harta mereka. sebab itu Maka wanita yang saleh, ialah yang taat kepada Allah lagi memelihara diri ketika suaminya tidak ada, oleh karena Allah telah memelihara (mereka)[290]. wanita-wanita yang kamu khawatirkan nusyuznya, Maka nasehatilah mereka dan pisahkanlah mereka di tempat tidur mereka, dan pukullah mereka. kemudian jika mereka mentaatimu, Maka janganlah kamu mencari-cari jalan untuk menyusahkannya. Sesungguhnya Allah Maha Tinggi lagi Maha besar. (Q.S an-Nisâ, 4: 34)

Dalam buku "Kemudahan dari Allah: Ringkasan Tafsir Ibnu Katsir" karya Muhammad Nasib Ar-Rifa'i, disebutkan Allah SWT berfirman, "Kaum lakilaki adalah pemimpin kaum perempuan", yakni laki-laki adalah pemimpin wanita, bertindak sebagai orang dewasa terhadapnya, yang menguasainya, dan pendidiknya tatkala dia melakukan penyimpangan. "Karena Alloh SWT telah mengunggulkan sebagian mereka atas sebagian yang lain". Yakni, karena kaum laki-laki itu lebih unggul dan lebih baik daripada wanita. Oleh karena itu, kenabian hanya diberikan kepada kaum laki-laki.

\section{METODE PENELITIAN}

Metode yang digunakan penulis adalah metode content analysis (analisis isi). Menurut Weber (1990: 9), analisis isi adalah metode penelitian yang digunakan untuk mengetahui simpulan sebuah teks, atau dengan kata lain, analisis isi merupakan metode penelitian yang ingin mengungkap gagasan penulis yang termanifestasi maupun yang laten. Penelitian ini juga menggunakan perspektif dan epistemologis feminis sebagai konsekuensi analisis gender. Dijelaskan oleh Sumadi (2017) bahwa feminist epistemology is an epistemology of social sciences to examine gender relation with power. The assumption is power produces science.10 Therefore, in feminist point of view, science isn't value-free. It assumes that science is developed due to a creator's ideology and interest. Science developed with patriarchal values causes marginalization of women. So, in application feminist epistemology is similar with mainstream epistemology, which broadly covers human sciences, such as moral, history, everyday knowledge, social, culture, or politic. The study is the same as general epistemology. However, woman factor and women's experiences become the basis of development and application of the study. Artinya bahwa perespektif gender menjadikan "perempuan" sebagai pembeda di antara metode penelitian umumnya.

Walaupun analisis isi pada awalnya berkembang dengan metode kuantitatif, namun belakangan berkembang juga analisis isi yang menggunakan metode kualitatif. Menurut Krippendorff (2004: 14), setidaknya ada empat jenis analisis isi yang menggunakan pendekatan kualitatif, salah satunya adalah analisis wacana (discourse analysisi). Secara sederhana analisis wacana mencoba memberikan pemaknaan lebih dari sekedar kata/frase atau kumpulan kata/frase yang di tulis oleh pengarang. 
Analisis wacana fokus pada bagaimana fenomena-fenomena partikular dimunculkan oleh pengarang teks.

\section{HASIL PENELITIAN DAN PEMBAHASAN}

Pandangan Imam Syafi'i tentang Hak Ijbar Wali

Imam Syafi'i berpendapat bahwa wali dalam pernikahan menjadi sesuatu yang harus ada, karena wali nikah termasuk salah satu rukun dalam pernikahan, yang berarti bahwa pernikahan tanpa adanya seorang ayah atau wali adalah tidak sah hukumnya, mesikpun di sisi lain wali tidak boleh mempersulit putrinya untuk menikah. Sebagaimana firman Allah SWT dalam surat an-Nisâ (4) ayat 34 tersebut di atas.

Ayat ini adalah ayat yang paling jelas yang menunjukkan bahwa perempuan merdeka tidak berhak menikahkan dirinya sendiri, meskipun pada perkembangannya ada salah satu Ulama komtemporer yang berpendapat bahwa wanita sah menikah tanpa wali. Sebagaimana juga ditunjukkan oleh al-Qur'an dalam surat al-Baqarah (2) ayat 232 yang telah disebutkan di atas.

Sebagian Ulama berkata bahwa ayat ini turun berkenaan dengan Ma'qil bin Yasar yang mencegah saudara perempuannya untuk kembali rujuk dengan suami pertamanya, al-Barrah Abdullah bin 'Asim. Ayat tersebut turun sebagai petunjuk bahwa perempuan tidak boleh menikahkan dirinya sendiri dan larangan bagi para wali untuk menolak menikahkan perempuan atau menjadi penghalang pernikahan bagi perempuan yang di bawah kewaliannya (Hidayat, 2009: 13).

Ayat ini juga banyak mengundang petunjuk bahwa pernikahan menjadi sempurna dengan adanya kerelaan wali, mahar dan calon mempelai, di lain pihak wali tidak boleh mempersulit putrinya. Oleh karena itu, jika dia mempersulit putrinya maka penguasa dapat menikahkannya, sebab orang yang menghalangi suatu hak, maka titah penguasa dapat mengambil hak itu dari sang wali (al-Syafi'i, 1983: 13). Sebagaimana ditunjukkan dalam sebuah hadits:

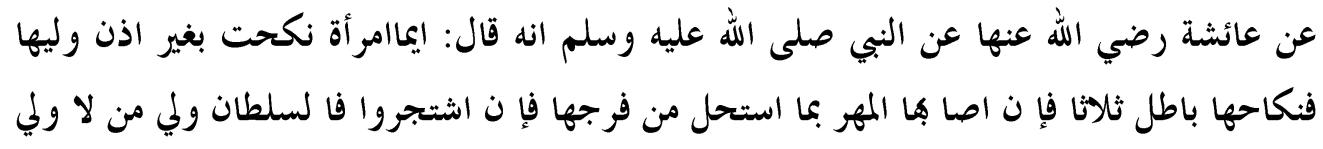

Dari Aisyah RA dariNabi SAW bahwasanya beliau bersabda: Siapapun perempuan yang menikah tanpa seizing walinya, maka nikahnya batal, nikahnya batal, nikahnya batal. Jika hubungan seksual telah terjadi (setelah pernikahan) maka perempuan itu berhak mendapatkan 
maharnya karena ia telah menghalalkan kehormatannya. Jika pihak wali enggan menikahkan, maka hakimlah yang bertinda ksebagai wali bagi seseorang yang tidak ada walinya. (Musnad Abu Dawud kitab an-Nikah bab fi al-wali hadits no. 1784)

\section{1) Perbedaan Al-Bikr dan Al-Tsayyib}

Dalam wilayah ijbar, terdapat pemaknaan yang berbeda antara perempuan yang masih gadis dan janda sehingga implikasi hukum terhadap keduanya juga berbeda. Yang dinamakan bikr adalah perempuan yang masih perawan dan menyerupai perawan. Dalam buku "Imam Syafi'i: Ringkasan kitab al-Umm" jilid II yang di tulis oleh Husain Abdu; Hamid Abu Nashir Nail, Imam Syafi'i mengatakan yang disebut perawan adalah apabila seorang perawan menikah berkali-kali dan semua suaminya itu meninggal dunia atau bercerai, dan si perawan telah menerima dari mereka mahar dan warisan, maka ia dapat dinikahkan sebagaimana halnya seorang perawan, baik para suami itu sempat dukhul atau belum asalkan mereka belum melakukan hubungan intim, karena pada kondisi demikian predikat perawan belum hilang darinya (Nail, tt: 443-444).

Sedangkan tsayyib adalah apabila seorang perempuan yang tidak lagi perawan atau apabila seorang wanita telah dicampuri oleh seorang laki-laki dalam pernikahan yang sah maupun pernikahan yang tidak sah atau dizinai, baik wanita itu telah baligh atau masih kecil, maka hukumnya sama seperti janda, tidak boleh bagi bapak menikahkannya tanpa izin darinya (Nail, tt: 444).

\section{2) Syarat Berlakunya Hak Ijbar Wali}

Seorang ayah dipersonifikasikan sebagai sosok yang begitu peduli pada anak perempuannya. Sebab sang gadis belum berpengalaman hidup berumah tangga. Disamping itu ia pun malu untuk mencari pasangan sendiri, maka Imam Syafi'i mencoba memberi sarana bagi ayah untuk membantu buah hatinya. Imam Syafi'i menentukan hak ijbar bagi seorang wali atas dasar kasih sayang yang begitu dalam terhadap anak perempuannya. Sebagaimana yang dikatakan Imam Syafi'i yang dikutip oleh Husain Abdu; Hamid Abu Nashir Nail, bahwa tidak ada hak bagi seorangpun selain bapak untuk menikahkan perawan atau janda yang masih kecil kecuali dengan restu darinya, dan tidak boleh pula menikahkan mereka hingga baligh lalu dimintai izin darinya. Apabila seseorang (selain bapak) menikahkan perempuan yang masih kecil, maka nikah itu dinyatakan batal. Pasangan suami istri itu tidak saling mewarisi dan tidak pula berlaku padanya talak, hukumnya sama seperti hukum nikah yang rusak semua sisinya. Dimana pernikahan ini tidak berkonsekuensi dengan adanya talak maupun warisan (Nail, tt: 444). Karenanya Imam Syafi'i hanya memberikan hak ijbar kepada ayah semata, walaupun dalam perkembangan 
selanjutnya Ulama Syafi'iyyah memodifikasi hak ijbar dengan memberikan kewenangan ijbar juga kepada kakek (Sopariyanti, 2008: 15).

3) Indikasi Kerelaan Gadis dan Janda terhadap Hak Ijbar Wali

Mengenai kebebasan dan persetujuan kaum wanita dalam perkawinan, Imam Syai'i mengklasifikasikan ke dalam tiga kelompok yaitu gadis yang masih kecil, gadis yang sudah baligh, dan janda. Untuk gadis yang berlum dewasa, batasan umurnya adalah di bawah 15 tahun atau belum keluar haid (Sopariyanti, 2008: 18). Dalam hal ini seorang ayah boleh menikahkan gadis tersebut tanpa izinnya terlebih dahulu, selama pernikahan tersebut tidak merugikan terhadap sang anak. Dasar pembolehan bapak menikahkan anaknya yang masih kecil adalah mengenai batasa minimal kedewasaan, Imam Syafi'i menetapkan bahwa batas minimal kedewasaan bagi anak adalah 15 tahun. Hal ini didasarkan pada hadits yang menjelaskan bahwa jihad dianjurkan bagi anak laki-laki yang telah berusia 15 tahun karena anak laki-laki yang telah berumur 15 tahun ini dianggap sudah dewasa, dan orang Islam mengambil batasan umur 15 tahun ini sebagai batas pemberlakuan hukum hadd (al-Syafi'i, 1983: 18). Hal ini sejalan dengan hadits Nabi Muhammad SAW yang diriwayatkan Aisyah:

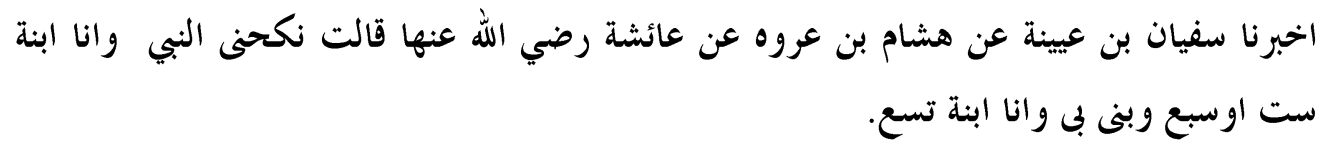

“Dari Hisyam bin Urwah dari bapaknya dari Aisyah RA berkata: Nabi menikahiku saat aku berumur 6 tahun atau 7 tahun dan membina rumah tangga denganku saat aku berumur 9 tahun".

Tindakan Nabi Muhammad SAW menikahi Aisyah pada usia masih 6 atau 7 tahun dan mengadakan hubungan setelah 9 tahun, ditambah dengan tindakan Abu Bakar yang menikahkan Aisyah yang masih belum dewasa, dengan alasan bahwa semua urusan anak kecil menjadi tanggung jawab ayahnya. Inilah kemudian menjadi dasar kebolehan menikahkan anak gadis yang masih kecil. Sedangkan perkawinan bagi anak gadis yang sudah dewasa, terdapat hak berimbang antara ayah dan anak gadisnya. Ketentuan ijbar ini diiringi anjuran untuk bermusyawarah dengan pihak-pihak yang hendak melangsungkan pernikahan dalam rangka mendapat izin atau persetujuan dari yang bersangkutan. Menurut Imam Syafi'i terhadap perntanyaan mengapa harus bermusyawarah dengan seorang gadis yang telah dewasa (al-Syafi'i, 1983: 19), sebagaimana firman Allah SWT:

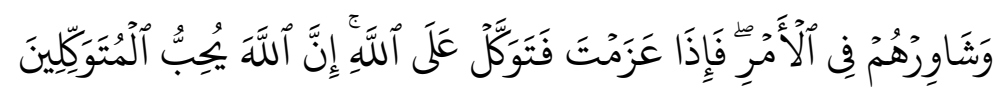

"Dan bermusyawarahlah dengan mereka dalam urusan itu". (Q.S Ali Imran, 3; 159) 
Mengenai bentuk persetujuan anak gadis dan janda yang mengindikasikan kerelaan mereka unutk dinikahkan, menurut Imam Syafi'i, anjuran untuk bermusyawarah terhadap anak gadis yang sudah dewasa hanya bersifat amru ikhtiyarin laa fardin (anjuran bukan keharusan). Karena hak ijbar ayah terhadap anak gadis yang sudah dewasa didasarkan pada mafhum mukhalafah dari hadits riwayat Muslim berikut ini:

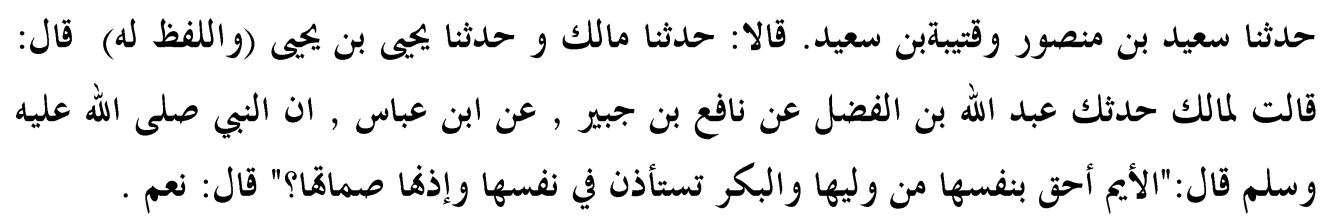

Telah menceritakan kepada kami Sa'id bin Manshur dan Qutaibah bin Sa'id, mereka berdua berkata: Telah menceritakan kepada kami Malik. Dan telah menceritakan kepada kami Yahya bin Yahya (dan lafadh ini miliknya), ia berkata: Aku berkata kepada Malik: Apakah 'Abdullah bin al-Fadhl pernah berkata kepadamu, dari Nafi', dari Ibnu 'Abbas: Bahwasanya Nabi SAW pernah bersabda:"Seorang janda lebih berhak atas dirinya daripada walinya, sedangkan anak gadis harus dimintai ijin persetujuan darinya. Sedangkan ijinnya adalah diamnya ?". Ia (Malik) menjawab: "Ya" ( HR Muslim no 1421)

Hadits di atas menyatakan bahwa janda lebih berhak atas dirinya. Mafhum mukhalafah hadits di atas adalah ketika janda berhak diberi hak untuk menentukan persetujuannya secara tegas maka pemahaman sebaliknya bahwa ayah lebih berhak menentukan urusan perkawinan anak gadisnya yang sudah dewasa, meskipun ada anjuran untuk bermusyawarah diantara kedua belah pihak. Dari penjelasan itu dapat diambil sebuah kesimpulan bahwa hak ayah melebihi hak anak gadisnya baik yang sudah dewasa maupun yang belum dewasa (al-Syafi'i, 1983: 19).

Adapun perkawinan seorang janda harus ada izin secara tegas dari yang bersangkutan. Keharusan ini didasarkan pada kasus perkawinan Khansa' binti Khidam yang di tolak oleh Rasulullah SAW karena Khansa' dikawinkan oleh bapaknya dengan seorang yang tidak disenangi dan tidak dimintai persetujuannya terlebih dahulu, adapun dasar hukumnya adalah sebagai berikut:

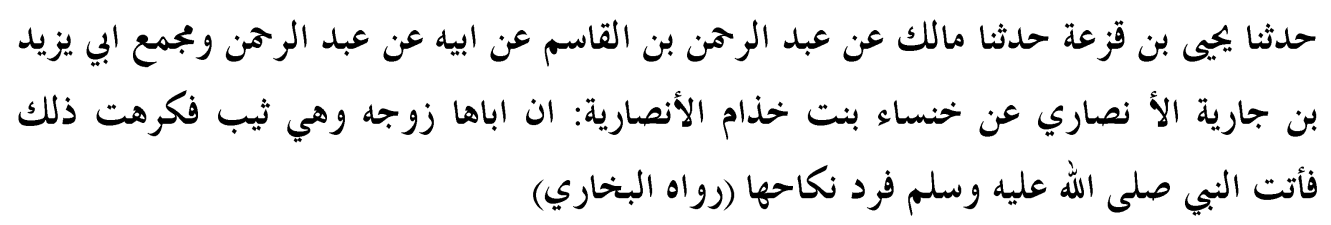

“Dari Khunasa binti Khidam sesungguhnya bapaknya telah mengawinkannya. Sedang Khunasa adalah seorang janda, maka ia 
datang menghadap Rasulullah SAW maka Rasulullah SAW menolaknya (membatalkan) nikahnya" (al-Bukhori juz VI, tt: 2547).

Hadits di atas mengatakan bahwa ketika bapak berkeinginan menikahkan anaknya yang sudah janda maka tidak boleh bagi bapaknya menikahkan kecuali harus dengan persetujuan yang tegas dari janda tersebut. Karena apabila bapak menikahkan janda tanpa ada persetujuan janda tersebut maka nikahnya tidak sah, kecuali jika janda tersebut menyuruh untuk melanjutkan dan membebaskan bapaknya untuk tetap melangsungkan pernikahan janda itu. Dengan demikian dapat dipahami bahwa seorang janda lebih berhak terhadap dirinya sendiri daripada walinya, dan validitas perkawinannya bergantung pada persetujuannya, dan tidak ada orang lain yang berhak mencegahnya untuk menikah (alSyafi'i, 1983: 18).

Menurut Muhammad (2002: 118) dalam karyanya ia menukil pendapat Imam Syafi'i yang mengatakan tujuan perkawinan pada hakikatnya adalah pembentukan keluarga yang bahagia. Akad perkawinan bukan semata-mata merupakan wahana bagi kepentingan dua orang mempelai (suami istri) melainkan keluarga mereka juga mempunyai peran yang penting. Seorang anak gadis pada umumnya kurang memiliki kecerdasan dalam memilih calon pasangan hidupnya. Sifat emosionalnya lebih menonjol dibandingkan dengan akalnya. Kondisi ini bisa mengkhawatirkan dia akan kawin dengan laki-laki yang salah. Unsur kerelaan anak perempuan atas calon suaminya pada anak gadis yang umumnya tertutup dan malu-malu, kerelaannya diindikasikan dengan diam saja dan tersenyum, atau dengan cara-cara lainnya yang oleh tradisi masyarakat dianggap sebagai sikap menyetujui atau minimal tidak menolak, sudah dianggap cukup sebagai bahan pertimbangan bagi kepentingan keluarganya.

Pada perempuan janda kerelaan tersebut diungkapkan secara terbuka, terang-terangan. Sikap keterbukaan seorang janda lebih disebabkan oleh karena pengalamannya dalam perkawinan. Karena pengalaman itu, dia memahami betul segala bentuk perkawinan, dalam hal ini berbeda dengan anak perempua yang gadis, dia belum berpengalaman dalam perkawinan dan seringkali dia merasakan kesulitan besar untuk mengemukakan pendapatnya secara terang-terangan, adalah benar bahwa perempuan dewasa berhak untuk bertindak sendiri dalam hal urusan-urusan $m u^{\prime}$ amalah maliyah (transaksi ekonomi), akan tetapi, dalam hal yang berkaitan dengan urusan seksual tidaklah bisa disamakan. Sebab persoalan seksual lebih berdimensi sensivitas dan emosional. Boleh jadi dalam tradisi masyrakat yang berkembang pada masa Imam Syafi'i, beberapa persyaratan diatas menjadi ukuran minimal bagi indikasi kerelaan seorang anak gadis untuk kawin dengan seorang laki-laki calon suaminya itu (Muhammad, 2002: 120). 


\section{Perspektif Gender terhadap Pandangan Imam Syafi'i tentang Hak Ijbar Wali}

Diberikannya hak ijbar bagi laki-lalki yang dalam hal ini adalah ayah untuk menikahkan anak perempuannya hanya memberikan keleluasaan bagi anak perempuan baik yang masih gadis maupun janda untuk memberikan persetujuan yang menunjukkan kerelaannya untuk dinikahkan. Adanya superioritas laki-laki terhadap perempuan mengakbibatkan anak perempuan kehilangan haknya untuk dapat memilih pasangan hidupnya sendri. Akar persoalan masalah ini karena Imam Syafi'i mendasarkan pendapatnya tentang hak ijbar wali terhadap surat an-Nisâ ayat 34 yang menerangkan besarnya superioritas laki-laki terhadap perempuan yang salah satunya adalah besarnya peran bapak terhadap peran publik-produktif anak perempuannya termasuk di dalamnya hal memilih pasangan sebagaimana disebutkan dalam surat an-Nisâ ayat 34 .

Surat an-Nisâ ayat 34 tersebut tampaknya memihak kepada laki-laki dan sebagaimana ditunjukkan, sudah sering digunakan para Ulama ortodoks untuk membuktikan superioritas laki-laki. Pertama, penting diketahui dalam konteks apa ayat ini diwahyukan. Dari penjelasan konteks diturunkannya ayat ini akan diketahui apa sebenarnya yang menjadi maksud kandungan al-Qur'an. Seorang penafsir terkemuka, Zamakhsyari, ketika menyoroti konteks pewahyuan ini, berkata bahwa seorang pemimpin Anshar, Sa'ad bin Rabi' menampar istrinya, Habibah binti Zaid, karena tidak taat kepadanya. Karena merasa tidak diperlakukan dengan baik, Habibah mengeluhkan kepada ayahnya, yang kemudian membawanya kepada Nabi Muhammad SAW. Sang ayah mengadu kepada Nabi Muhammad SAW bahwa putrinya telah ditampar oleh suaminya karena ketidaktaatannya. Nabi Muhammad SAW menganjurkan untuk membalas, adanya pernyatan Nabi Muhammad SAW yang kontroversial dengan menganjurkan untuk membalas, jelas menimbulkan kegemparan para lakilaki di Madinah mengingat pada waktu itu masyarakat Madinah yang menganut sistem patriarkal. Namun sebenarnya tindakan Nabi Muhammad SAW itu, memiliki tujuan untuk mencegah dan menghapus secara bertahap pemukulan terhadap istri yang marak pada zaman Nabi Muhammad SAW (Engineer, 1994: 64-65).

Imam Syafi'i mengartikan kata qawwam diatas dengan pemimpin. Pemaknaan dengan arti pemimpin ini dikarenakan masih mengakar kuatnya budanya patriarkhi yang berkembang melingkupi lingkungan budaya di zaman kehidupan Imam Syafi'i. Memang banyak penafsir terdahulu, di bawah pengaruh etos aba pertengahan telah memakainya sebagai dukungan yang suci pada superioritas laki-laki. Beberapa penafsir konservatif India menerjemahkan kata qawwam dalam bahasa urdu dengan darogha (yakni, laki-laki adalah sebagai pegawai polisi bagi perempuan). Meskipun begitu, kaum modernis yang ingin menegakkan persamaan jenis kelamin membaca ayat ini dengan sangat berbeda. Muhammad Asad, 
penafsir modernis terkemuka misalnya, menerjemahkan ayat di atas dengan: "Laki-laki hendaknya menjaga perempuan sepenuhnya dengan bertanggung jawab karena Allah SWT telah melimpahkan lebih banyak beban kepada laki-laki daripada perempuan dan dengan apa yang mereka nafkahkan dari apa yang mereka miliki. Dan perempuan yang bertakwa adalah yang paling beriman, yang memelihara kerukunan yang telah (ditakdirkan) Allah SWT untuk dipelihara. Dan bagi (mereka) perempuan yang sakit hati, kamu mempunyai alasan untuk takut maka pertama nasihatilah mereka, kemudian tinggalkanlah sendiri di tempat tidur, kemudian pukullah mereka, dan apabila memberikan perhatian kepadamu, janganlah mencari kesalahan untuk menyusahkan mereka. Sesungguhnya Allah SWT jelas Maha Tinggi lagi Maha Besar" (Engineer, 1994: 69).

Dari sini, kata qawwam yang menjadi kata kunci di ayat itu, telah diterjemahkan secara sangat berbeda oleh para penafsir lain. Dalam terjemahan ini tekanannya bukan pada superioritas laki-laki atas perempuan, tetapi kewajiban laki-laki untuk menjaga perempuan. Kata qawwam telah diterjemahkan dengan seseorang yang harus menjaga perempuan secara penuh. Bahkan Maulana Asad merasa bahwa kata qawwam adalah bentuk yang dikuatkan dari $q a^{\prime} i m$, dan bentuk gramatikal ini lebih komprehensif karena menggabungkan konsep nafkah fisik dan perlindungan dan tanggung jawab moral. Oleh karena itu, menurut Maulana Asad, menjadi qawwam berarti memberikan tanggung jawab lakilaki kepada perempuan. Penting juga untuk dicatat, dalam konteks apa Allah SWT telah memberikan laki-laki fadhl (yakni, prefensi atau kelebihan) atas perempuan (Engineer, 1994: 70).

Dalam pandangan Mernisi, kata qawwam ini telah dialih bahasakan secara bervariasi, ada yang mengartikan sebagai pelindung dan pemelihara (perempuan), berkuasa (terhadap perempuan), memiliki keunggulan (di atas perempuan), dan yang berdaulat atau penguasa (atas perempuan). Secara linguistik, kata qawwam berarti pencari nafkah atau mereka yang menyediakan sarana pendukung kehidupan. Titik logis yang mesti dibuat disini, bahwa kalimat pertama bukan merupakan pernyataan deskriptif yang menyatakan semua laki-laki dalam kenyataannya adalah pemberi nafkah perempuan, karena jelas ada, paling tidak beberapa laki-laki tidak memberikannya. Apa yang dinyatakan oleh kalimat tersebut agaknya adalah laki-laki harus memiliki kemampuan untuk memberi nafkah. Dengan kata lain, statemen ini sesungguhnya merupakan statemen normatif menyangkut konsep Islam tentang pembagian kerja dalam sebuah struktur keluarga atau masyarakat. Kentayaan laki-laki adalah qawwamun tidak lalu berarti perempuan tidak bisa atau tidak boleh memberi nafkah untuk diri mereka sendiri, tapi hanya karena mengingat beban berat yang dipikul karena kebanyakan perempuan harus melahirkan dan membesarkan anak, 
mereka tidak harus memiliki kewajiban tambahan mencari nafkah pada waktu yang bersamaan (Mernisi, 1995: 91).

Apa yang penting dalam bagian pertama ayat ini adalah pembagian kerja fungsional yang perlu untuk mempertahankan keseimbangan dalam masyarakat. Laki-laki tidak harus memenuhi kewajiban beranak tapi diberi tugas untuk mencari nafkah. Perempuan dibebaskan dari tugas sebagai pemberi nafkah agar mereka bisa memenuhi fungsi beranak. Kedua fungsi tersebut terpisah namun saling melengkapi dan tidak ada yang lebih tinggi atau lebih rendah (Mernisi, 1995: 92).

Pendapat Maulvi Mumtaz Ali, seorang advokat pembela hak-hak perempuan, yang tertulis dalam buku karya Asghar Ali Engineer, mengatakan bahwa qawwam adalah kepanjangan dari kata qiyam yang berarti orang yang harus lebih banyak bekerja di luar rumah untuk bekerja dan mencari nafkah kehidupan. Dalam pengertian inilah bahwa laki-laki adalah qawwam bagi perempuan. Dia (Maulvi Mumtaz Ali) membuat sebuah argumentasi yang menarik bahwa daripada membuktikan superioritas lakilaki terhadap perempuan, ayat ini membuktikan bahwa laki-laki harus bekerja untuk kehidupan yang menyenangkan bagi perempuan. Dengan demikian, laki-laki dalam posisinya melayani perempuan (Engineer, 1994: 225).

Pendapat serupa juga dikemukakan oleh Nasr Hamid Abu Zayd, beliau mengemukakan bahwa ayat qawwamah tersebut merupakan bentuk ketetapan Ilahi untuk melebihkan sebagian manusia atas sebagian yang lain. Maksud ketetapan itu adalah pendeskripsian perbedaan sosial dan ekonomi yang berlaku diantar manusia, yaitu perbedaan-perbedaan yang disebabkan oleh hukum gerak sosial atau disebabkan oleh hukum-hukum yang muncul sesuai dengan kondisi wacan al-Qur'an pada jalan dan hukum-hukum Ilahi yang bersifat sosiologis yang dapat berubah karena hukum yang berkembang (Zayd, 2003: 191-192).

Kalaupun deskripsi tersebut dianggap deskripsi tasyri', arti qawwamah bukan merupakan kekuasaan mutlak yang buta, dalam artian mengontrol dan memonopoli dengan kewenangan laki-laki untuk mengambil keputusan dan mewajibkan ketertundukkan mutlak dan buta kepada perempuan (istri) karena qawwamah adalah pelaksanaan tanggung jawab ekonomi dan sosial. Jadi qawwamah adalah tanggung jawab yang ditanggung oleh orang mampu dari dua pihak, laki-laki atau perempuan, atau kerjasama antara keduanya sesuai dengan tingkat kesulitan kondisi dan situasinya (Zayd, 2003: 193).

Permasalahan yang melingkupi surat an-Nisâ ayat 34 ini sebenarnya terletak pada masalah kesadaran sosial dan penafsiran yang tepat. Kesadaran kaum perempuan pada masa turunnya ayat itu tidak diragukan lagi masih sangat rendah dan pekerjaan domestik dianggap sebagai 
kewajiban perempuan. Lebih dari itu, laki-laki mengaggap dirinya sendiri lebih unggul karena kekuasaan dan kemampuan mencari nafkah dan membelanjakannya untuk perempuan. Al-Qur'an tidak mencerminkan situasi sosial itu, al-Qur'an hanya mengatakan bahwa laki-laki adalah qawwam (pemberi nafkah atau pengatur urusan keluarga) dan tidak mengatakan bahwa mereka harus menjadi qawwam. Dapat dilihat bahwa qawwam merupakan sebuah pernyataan kontekstual bukan normatif. Seandainya al-Qur'an mengatakan bahwa laki-laki harus menjadi qawwam, maka ia akan menjadi sebuah pernyataan normatif dan pastilah akan mengikat bagi semua perempuan pada semua zaman dan dalam semua keadaan. Tetapi Allah SWT tidak menginginkan hal itu (Engineer, 1994: 6263).

Apabila kesadaran kaum perempuan sudah tumbuh, bahwa peranperan domestik yang mereka lakukan harus dinilai dan diberi ganjaran yang serupa sesuai dengan doktrin yang diajarkan al-Qur'an. Bukan semata-mata kewajiban yang harus mereka lakukan, namun perlindungan dan nafkah yang diberikan lak-laki terhadap mereka tidak dapat lagi dianggap sebagai keunggulan laki-laki, karena peran-peran domestik yang dilakukan perempuan, maka laki-laki harus mengimbanginya dengan melindungi dan memberi nafkah kepada perempuan sebagai qawwam itu. Dengan jalan pikiran itu, Engineer menyatakan bahwa pernyataan ar-rijalu qawwamun 'ala an-nisâ bukanlah pernyataan normatif, tapi pernyataan kontekstual (Engineer, 1994: 63).

Berbeda dengan Engineer, Amina Wadud Muhsin secara eksplisit mengakui bahwa laki-laki menjadi pemimpin bagi perempuan. Akan tetapi, kepemimpinannya itu harus disertai syarat: jika laki-laki punya atau sanggup membuktikan kelebihannya dan kedua, jika laki-laki mendukung perempuan dengan menggunakan harta bendanya. Kelebihan yang dimaksud di sini adalah karena laki-laki mendapatkan harta warisan dua kali lipat dibanding perempuan, dan karena itu berkewajiban memberikan nafkah bagi perempuan. Jadi terdapat hubungan timbal balik antara hak istimewa yang diterima laki-laki dengan tanggung jawab yang dipikulnya. Tanpa terpenuhi kedua syarat tersebut maka laki-laki bukanlah pemimpin bagi perempuan (Muhsin, 1994: 93-94).

Dengan pengertian seperti itu bagi Muhsin, kelebihan itu tidak harus bersyarat, karena surat an-Nisâ ayat 34 mengatakan "mereka" (jamak maskulin) telah dilebihkan atas "mereka" (jamak feminim). Ayat itu menyebutnya $b a^{\prime} d h$ (sebagian) di antara mereka atas $b a^{\prime} d h$ (sebagian lainnya). Penggunaan kata $b a^{\prime} d h$ berhubungan dengan hal-hal nyata yang teramati pada manusia. Tidak semua laki-laki unggul atas perempuan dalam segala hal. Sebagian laki-laki memiliki kelebihan atas sebagian perempuan dalam hal tertentu, begitupun sebaliknya, perempuan juga 
memiliki kelebihan atas laki-laki dalam hal-hal tertentu. Jadi, jika Allah telah menetapkan kelebihan sesuatu atas yang lainnya, itu tidak berarti maknanya absolut terus (Muhsin, 1994: 94).

Dari penjelasan para aktifis gender di atas, dapat disimpulkan bahwa kata qawwam adalah bentuk kepemimpinan kolektif kolegia antara laki-laki dan perempuan, dengan tujuan saling melengkapi satu sama lain, kalaupun dikatakan sebagai kepemimpinan normatif, tujuan kepemimpinan laki-laki tersebut untuk melindungi, menjaga dan memberi nafkah bagi perempuan bukan untuk mendiskriminasi. Jadi, kata qawwam tidak bisa dijadikan sebagai alat legitimasi adanya superioritas laki-laki untuk mendiskriminasi hak-hak perempuan termasuk di dalamnya adalah hak anak perempuan dalam hal memilih pasangannya sendiri. Karena kata qawwam tersebut mengisyaratkan kepada laki-laki dan perempuan untuk saling melengkapi satu sama lain bukan untuk mendiskriminasi perempuan, karena hakikatnya laki-laki dan perempuan memiliki hak dan kewajiban yang setara dalam mengurus rumah tangga. Maka dari itu, hak ijbar yang dimiliki ayah tidak bisa dibenarkan karena hal tersebut menghilangkan hak anak perempu an untuk bisa memilih pasangangannya sendiri.

Pernikahan adalah akad yang menghalalkan pergaulan serta menyebabkan terjadinya hak dan kewajiban serta tolong menolong antara seorang laki-laki dengan seorang perempuan yang bukan mahram. Pada hakikatnya laki-laki dan perempuan diciptakan Allah SWT guna menjadikan keduanya pasangan yang lengkap dan agar saling mengenal. Atas dasar itu, prinsip al-Quran terhadap hak laki-laki dan perempuan adalah sama, hak isteri diakui secara adil dengan hak suami. Keduanya memiliki hak dan kewajiban masing-masing. Oleh sebab itu, perkawinan tidak saja dipandang sebagai media mereleasasikan syari'at Allah agar memperoleh kebaikan di dunia dan di akhirat, tetapi juga merupakan sebuah kontrak perdata yang akan menimbulkan hak dan kewajiban antar keduanya

Perkawinan bertujuan untuk membina keluarga yang bahagia, diliputi rasa cinta dan kasih sayang dan diridhai Allah SWT. Tujuan ini akan tercapai apabila calon-calon mempelai telah saling suka menyukai untuk mengadakan ikatan perkawinan. Saling suka menyukai ini dalam bentuk yang lahir berupa izin dan persetujuan pihak-pihak yang akan melakukan perkawinan itu sendiri. Karena pihak wanita tidak secara langsung melaksanakan ijab, maka agama mengisyaratkan adanya izin dan persetujuan dari seorang wanita sebelum dilaksanakan perkawinannya.

Pada kenyataannya seringkali masih kita jumpai sebagian masyarakat yang memahami ajaran Islam dari arah figh secara sempit. Salah satu akibat sempitnya dalam memahami ajaran figh ini adalah masih mengakar kuatnya budaya kawin paksa. Hal ini terjadi karena dalam tradisi masyarakat Indonesia masih terdapat anggapan yang sangat kuat bahwa jodoh bagi 
anak laki-laki adalah urusan Tuhan, tetapi bagi anak perempuan adalah urusan orang tua yang dalam hal ini adalah bapaknya.

Imam Syafi'i dan Ulama yang lain menetapkan hak ijbar bagi seorang wali atas dasar kasih sayangnya yang mendalam terhadap putrinya itu. Seorang ayah adalah sosok yang begitu peduli pada kebahagiaan anak gadisnya. Sebab sang gadis belum berpengalaman hidup berumah tangga, disamping biasanya ia pun malu untuk mencari pasangan sendiri, sehingga para Ulama mencoba memberikan saran bagi ayah untuk membantu buah hatinya itu.

Pemahaman akan makna ijbar tersebut dapat memberikan batas yang jelas antara wali mujbir dengan kawin paksa. Wali mujbir lebih merupakan wujud kekukasaan sang ayah terhadap anak perempuannya untuk menikahkannya dengan seorang laki-laki, bukanlah suatu tindakan memaksa kehendaknya sendiri dengan tidak memperhatikan kerelaan sang anak, melainkan hanyalah hak menikahkan.

Mengenai persetujuan kaum wanita dalam perkawinan, Imam Syai'i mengklasifikasikan ke dalam tiga kelompok. Pertama: gadis yang masih kecil, sang ayah boleh menikahkannya tanpa izin dari anak tersebut, asalkan tidak merugikan sang anak. Kedua: gadis yang sudah baligh, sang ayah tidak boleh menikahkan anak gadis yang sudah baligh atau sudah dewasa tanpa izin darinya dengan indikasi diamnya. Ketiga: janda, ayah tidak boleh menikahkannya tanpa sseizinnya, izin dari seorang janda harus secara terang-terangan. Sebagaimana hadits Nabi Muhammad SAW:

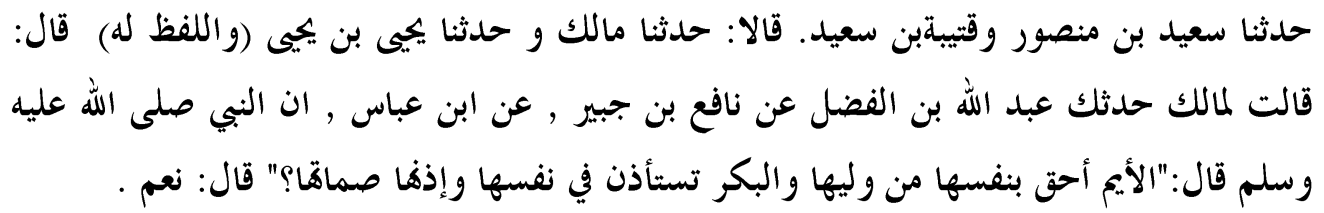

Telah menceritakan kepada kami Sa'id bin Manshur dan Qutaibah bin Sa'id, mereka berdua berkata: Telah menceritakan kepada kami Malik. Dan telah menceritakan kepada kami Yahya bin Yahya (dan lafadh ini miliknya), ia berkata: Aku berkata kepada Malik: Apakah 'Abdullah bin al-Fadhl pernah berkata kepadamu, dari Nafi', dari Ibnu 'Abbas: Bahwasanya Nabi SAW pernah bersabda:"Seorang janda lebih berhak atas dirinya daripada walinya, sedangkan anak gadis harus dimintai ijin persetujuan darinya. Sedangkan ijinnya adalah diamnya ?". Ia (Malik) menjawab: "Ya" ( HR Muslim no 1421)

Imam Syafi'i berpendapat bahwa wali dalam pernikahan menjadi sesuatu yang harus ada, karena wali nikah termasuk salah satu rukun dalam pernikahan, yang berarti bahwa pernikahan tanpa adanya seorang ayah atau wali adalah tidak sah hukumnya, mesikpun di sisi lain wali tidak boleh 
mempersulit putrinya untuk menikah, sebagaimana firman Allah SWT dalam surat an-Nisâ (4) ayat 34 di atas.

Surat an-Nisâ (4) ayat 34 di atas tampaknya memihak kepada laki-laki dan sebagaimana ditunjukkan, sudah sering digunakan para Ulama ortodoks untuk membuktikan superioritas laki-laki. Pertama, penting diketahui dalam konteks apa ayat ini diwahyukan. Dari penjelasan konteks diturunkannya ayat ini akan diketahui apa sebenarnya yang menjadi maksud kandungan al-Qur'an. Seorang penafsir terkemuka, Zamakhsyari, ketika menyoroti konteks pewahyuan ini, berkata bahwa seorang pemimpin Anshar, Sa'ad bin Rabi' menampar istrinya, Habibah binti Zaid, karena tidak taat kepadanya. Karena merasa tidak diperlakukan dengan baik, Habibah mengeluhkan kepada ayahnya, yang kemudian membawanya kepada Nabi Muhammad SAW. Sang ayah mengadu kepada Nabi Muhammad SAW bahwa putrinya telah ditampar oleh suaminya karena ketidaktaatannya. Nabi Muhammad SAW menganjurkan untuk membalas, adanya pernyatan Nabi Muhammad SAW yang kontroversial dengan menganjurkan untuk membalas, jelas menimbulkan kegemparan para lakilaki di Madinah mengingat pada waktu itu masyarakat Madinah yang menganut sistem patriarkal. Namun sebenarnya tindakan Nabi Muhammad SAW itu, memiliki tujuan untuk mencegah dan menghapus secara bertahap pemukulan terhadap istri yang marak pada zaman Nabi Muhammad SAW.

Apabila kesadaran kaum perempuan sudah tumbuh, bahwa peranperan domestik yang mereka lakukan harus dinilai dan diberi ganjaran yang serupa sesuai dengan doktrin yang diajarkan al-Qur'an. Bukan semata-mata kewajiban yang harus mereka lakukan, namun perlindungan dan nafkah yang diberikan lak-laki terhadap mereka tidak dapat lagi dianggap sebagai keunggulan laki-laki, karena peran-peran domestik yang dilakukan perempuan, maka laki-laki harus mengimbanginya dengan melindungi dan memberi nafkah kepada perempuan sebagai qawwam itu. Dengan jalan pikiran itu, Engineer menyatakan bahwa pernyataan ar-rijalu qawwamun 'ala an-nisâ bukanlah pernyataan normatif, tapi pernyataan kontekstual.

Dari penjelasan di atas, dapat disimpulkan bahwa kata qawwam adalah bentuk kepemimpinan kolektif kolegia antara laki-laki dan perempuan, dengan tujuan saling melengkapi satu sama lain, kalaupun dikatakan sebagai kepemimpinan normatif, tujuan kepemimpinan laki-laki tersebut untuk melindungi, menjaga dan memberi nafkah bagi perempuan bukan untuk mendiskriminasi.

Dari penjelasan di atas, dapat ditemukan persamaan dan perbedaan antara Imam Syafi'i dan aktifis gender tentang hak ijbar. Persamaannya adalah bahwa Imam Syafi'i dan gender berpendapat bahwa janda tidak boleh dipaksa untuk menikah. Adapun perbedaannya adalah dalam hal anak perempuan yang masih perawan baik yang masih kecil ataupun yang sudah dewasa (sudah baligh), menurut Imam Syafi'i seorang ayah boleh 
memaksa anak perempuannya tanpa meminta izin darinya. Sedangkan menurut aktifis gender tidak boleh.

\section{KESIMPULAN}

Melalui uraian data dana analisi yang telah diuraikan dan dijelaskan pada bab sebelumya, dapat ditarik simpulan sebagai berikut: (1) Imam Syafi'i memberlakukan hak ijbar wali ke dalam tiga kelompok: (a) bagi anak kecil yang belum dewasa, ayahnya dapat menikahkannya tanpa harus meminta persetujuannya terlebih dahulu; (b) bagi anak gadis yang sudah dewasa yaitu yang sudah berusia 15 tahun atau sudah mimpi basah atau sudah mengeluarkan darah haidh, ayahnya dapat menikahkannya tanpa meminta persetujuannya terlebih dahulu, meskipun ada anjuran untuk bermusyawarah dengan anak gadis yang sudah deawas tersebut, tapi anjuran tersebut sifatnya amrun ikhtiyarin la fardhin; dan (c) bagi anak perempuan yang sudah janda, ayahnya harus meminta izin kepada janda untuk menikahkannya, dan izin dari janda tersebut harus diungkapkan secara tegas dengan perkataannya. Sedangkan bagi anak gadis cukup dengan diamnya saja. (2) Hak ijbar yang diberlakukan Imam Syafi'i kepada anak gadis dan janda, menurut pendapat aktifis gender tidak mencerminkan keadilan gender. Karena menurut aktifis gender, kata qawwam yang menjadi landasan hak ijbar Imam Syafi'i tidak mengisyaratkan kepemimpinan lakilaki terhadap perempuan secara mutlak dalam segala hal yang termasuk didalamnya adalah mengurusi urusan publik perempuan yang diantarnya memilih pasangan. Namun kepemimpinan seorang laki-laki yang dimaksud hanyalah dalam bidang tertentu saja yang dalam hal ini mencarikan nafkah dan memberi mahar.

\section{DAFTAR PUSTAKA}

Abbas, Sirajuddin. (2004). Sejarah dan Keagungan Madzhab Syafi'i. Jakarta: Pustaka Tarbiyah.

Al-'Aqil, Muhammad bin A.W. (2008). Manhaj Aqidah Imam Syafi'i. Jakarta: Pustaka Imam as-Syafi'i

Al-'Aqil, Muhammad bin A.W. (2015). Biografi Imam Asy-Syafi'i. Jakarta: Pustaka Imam as-Syafi'i hal 15-51.

Al-Anshori, Abu Vida'. (2006). Mukhtashar Kitab al-Umm. Kudus: Pustaka Setia.

Al-Bukhori, Al-Ja'fy Muhammad bin Ismail Abu Abdillah, Shohih Bukhori, Juz VI, Beirut: Dar Ibnu Katsir, tt. 
Al-Daruquthny, Sunan Daruquthniy, No 11, juz III. (CD Maktabah Syamelah: http//:www.shamela.ws).

Al-Hayali, Kamil. (2005). Solusi Islam dalam Konflik rumah tangga, diterjemahkan oleh Noor Hasanuddin, Jakarta: Raja Grafindo Persada

Ali, et.al. (2014).Ar-Rahman The Inspire Al-qur'anul Karim. Cet-1. Jakarta: CV. Al-eQolam Publishing

Al-Jamal, M. Hasan. (2005). Biografi 10 Imam Besar. Diterjemahkan oleh M.Khaled Muslih dan M. Imam Awaluddin. Jakarta: Pustaka alKautsar.

Al-Nasa'i, (tt), Sunan Nasa'i, Juz VI, Beirut: Dar al-Fikr.

Al-Syafi'i, Abi Abdillah Muhammad bin Idris. (1983). Al-Umm. Beirut: Dar al-Fiqr

Arikunto, Suharsimi. (1987). Prosedur Penelitian. Jakarta: PT Remaja Rosdakarya

Ar-Rifa'i, Muhammad Nasib. (1999). Kemudahan dari Allah: Ringkasan Tafsir Ibnu Katsir. Diterjemahkan oleh Syihabuddin, cet. 1. Jakarta: Gema Insani.

Aziz, Abdul., et.al. (2015). Buku Saku: Gender, Islam dan Budaya. Surabaya: Pusat Studi Gender dan Anak (PSGA) UIN Sunan Ampel Surabaya.

Daly,Peunoh. (1998). Hukum Perkawinan Islam, Studi Perbandingan dalam Kalangan Ahlus Sunnah dan Negara-negara Islam, Jakarta:Bulan Bintang,.

Dawud, Sulaiman Abu. (tt), Sunan Abu Dawud, juz I Beirut: Dar al-Fikr.

Dewi, Ririn Rindiana. (2017). Persetujuan Mempelai Perempuan dalam Pernikahan Perspektif Hadis (Kajian Mukhtalif al-Hadits). Skripsi. Jakarta: UIN Syarif Hidayatullah.

Effendi, Djohan. (1991). Ensiklopedia Nasional Indonesia, XVIII. Jakarta: PT.Cipta Adi Pustaka.

Engineer, Asghar Ali. (1994). Hak-hak Perempuan dalam Islam, diterjemahkan oleh Farid Wajidi dan Cici Farkha Assegaf. Yogyakarta: Bentang.

Engineer, Asghar Ali. (2003).Pembebasan Perempuan, diterjemahkan oleh Agus Nuryanto, Yogyakarta: LkiS.

Hasanah, Uswatun. (2005), "Hak Kewalian Seorang Janda atas Dirinya (Studi Fenomenologi Pembatalan Perkawinan Oleh Pengadilan Agama Mojokerto Atas Seorang Janda yang Berumah Tangga Lebih Dari Satu Tahun)", Skripsi, Malang: UIN Malang.

Hermanto, Agus. (2017). Teori Gender Dalam Mewujudkan Kesetaraan: Menggagas Fikih Baru. AHKAM, 5(2), 209-230 
Hernawati \& Mukhlisin. (2008). Menuju Pernikahan Islami. Karanganyar: Genius Komputer.

Hernawati, Tanti. (2007). Budaya Jawa dan Kesetaraan Gender. Jurnal Komunikasi Massa. 01 (01), 18-24

Hidayat, Taufiq. (2009), Rekonstruksi Hak Ijbar, De Jure I. Malang: P3M Fak. Syariah UIN Malang.

Ilyas, Yunahar. (2006), Kesetaraan Gender dalam Al-Qur'an: Studi Pemikiran Para Mufassir. Yogyakarta: LABDA Press.

Irham dan Asmu'i Taman, Masturi. (2005). 60 Biografi Ulama Salaf. Jakarta: Pustaka al-Kautsar.

Ismail, Nurjannah. (2003). Perempuan dalam Pasungan: Bias Laki-Laki dalam Penafsiran, Yogyakarta: LkiS.

Kamal, Mustofa. (2003), "Ijbar dan Kebebasan Wanita dalam Menentukan Pasangan Perspektif Mahmud Syaltut", Skripsi. Yogyakarta: UIN Sunan Kalijaga Yogyakarta.

Khusna, Khotimatul. (2003), "Relevansi Hak Ijbar Wali Menurut Imam Syafi'i Dengan Hak Perempuan dalam Memilih Pasangan, Skripsi. Yogyakarta: UIN Sunan Kalijaga Yogyakarta.

Krippendorff, Klaus. (2004), Content Analysis: An Introduction to its Methodology (Second Edition), California: Sage Publication.

Mernisi dan Riffat Hasan, Fatimah. (1995), Setara di hadapan Allah: Relasi Lakilaki dan Perempuan dalam Tradisi Islam Pasca Patriarkhi, diterjemahkan LSPPA. Yogyakarta: Media Gama Offset.

Millet, Kate. (2009). Sexsual Politik, dalam Zaenal Mahmudi, Sosiologi Fiqh Perempuan. Malang: UIN Malang Press.

Moleong, Lexy J. (2012).Metodologi Penelitian Kualitatif edisi Revisi, Bandung: Rosda.

Mubarok, Jaih. (2002). Modifikasi Hukum Islam Studi Tentang Qaul Qadim dan Qaul Jadid. Jakarta: PT. Raja Grafindo Persada.

Muchtar, Kamal. (1993). Asas-Asas Hukum Islam tentang Perkawinan. Cet ke-3. Jakarta: Bulan Bintang.

Muhammad, Husein. (2002). Figh Perempuan: refleksi kiyai atas wacana agama dan gender. Yogyakarta: LKIS.

Muhsin, Amina Wadud. (1994). Wanita di dalam al-Qur'an, terjemahan Yaziar Radianti. Bandung: Pustaka.

Mukti, MH. (2004). Asy-Syafi'i sebagai Bapak Ushul Fiqh, Ibda 1. Purwokerto: P3M STAIN Purwokerto 
Munawir, Ahmad Warson. (1997). Kamus al-Munawir. Surabaya: Pustaka Progresif.

Nail, Husain Abdul Hamid. (tt). Imam Syafi'i: Ringkasan Kitab al-Umm Jilid 2.

Nugroho, Riant. (2008). Gender dan Strategi Pengarus-Utamaannya di Indonesia. Cet. I. Yogyakarta: Pustaka Pelajar.

Rasyid, Sulaiman. (2002). Fiqh Islam, Cet. Ke 34, Bandung: Sinar Baru Algesindo.

Sabiq, Sayid. (2007) Fiqhu al-Sunnah, Fiqih Sunnah, Terj. Nor Hasanuddin, dkk., Jakarta Pusat: Pena Pundi Aksara, Cetakan ke-II,

Saebani, Beni Ahmad. (2008). Metodologi Penelitian. Bandung: Pustaka Setia

Sahrani, Sohari. (2009). Fikih Munakahat. Jakarta: Rajawali Pers.

Salam, Nor. (2010). Studi atas Hadits La Nikaha Illa Bi Waliyyin: Analisis Ilmu Hadits," Skripsi. Malang: UIN Maliki Malang

Sumadi (2017) “The Development Of Feminist Epistemology In Islamic Studies In Indonesian University, A Case Study Of Akhwal Syaikhsiyah Study Program Of Darussalam Islamic Institute, Ciamis West Java" Jurnal Epistemé, Vol. 12, No. 1, Juni 2017, hal 232-259

Sopariyanti, Pera. (2008). Kawin Paksa Perspektif Fiqh dan Perlindungan Anak. Jakarta: RAHIMA.

Summa, Muhammad Amin. (2004). Hukum Keluarga Islam di Dunia Islam, Jakarta, Rajawali Pers

Syarifuddin, Amir. (2006) Hukum Perkawinan Islam di Indonesia. Jakarta: Kencana

Tim Penyusun Kamus Pusat Penelitian dan Pengembangan Bahasa. (1989). Kamus Besar Bahasa Indonesia. Jakarta: Balai Pustaka.

Weber, Robert Philiph. (1990), Basic Content Analysis, California: Sage Publication.

Yatim, Badri. (1994). Sejarah Peradaban Islam. Jakarta: PT. Raja Grafindo Persada.

Zahrah, M. Abu. (2007). Imam Syafi'i: Biografi dan Pemikiran dalam Masalah Akidah, Politik dan Fikih. Jakarta: Lentera.

Zaprulkhan. (2015). Kesetaraan Gender Dalam Perspektif Al-Qur'an (Studi Kritis Pemikiran Nasaruddin Umar). EDUGAMA, 01 (01), 108-135

Zayd, Nasr Hamid Abu. (2003). Dekontruksi Gender: Kritik Wacana Perempuan dalam Islam. Diterjemahkan oleh M. Nur Ichwan dan M. Syamsul Hadi. Jakarta: SAHMA. 